\title{
New records of recently described Zebrus pallaoroi (Actinopterygii: Gobiiformes: Gobiidae) with notes on its morphology, ecology, and molecular identification
}

\author{
Marcelo KOVAČIĆ ${ }^{1}$, Branko DRAGIČEVIĆ ${ }^{2}$ Mišo PAVIČIĆ ${ }^{2}$, Iva ŽUŽUL², Tanja ŠEGVIĆ-BUBIĆ2 \\ 1 Natural History Museum Rijeka, Rijeka, Croatia \\ 2 Institute of Oceanography and Fisheries, Split, Croatia
}

http://zoobank.org/76C255DB-D1B3-4570-929A-1ECA049A92B8

Corresponding author: Branko Dragičević (brankod@izor.hr)

Academic editor: Paraskevi Karachle • Received 23 December 2021 • Accepted 8 February 2022 • Published 8 March 2022

Citation: Kovačić M, Dragičević B, Pavičić M, Žužul I, Šegvić-Bubić T (2022) New records of recently described Zebrus pallaoroi (Actinopterygii: Gobiiformes: Gobiidae) with notes on its morphology, ecology, and molecular identification. Acta Ichthyologica et Piscatoria 52(1): 13-19. https://doi.org/10.3897/aiep.52.79723

\begin{abstract}
The family Gobiidae represents the species-richest family of fishes in the Mediterranean Sea. However, many Mediterranean gobiid species are poorly known with just one or few species records in total. Among those species, the recently described Zebrus pallaoroi Kovačić, Šanda et Vukić, 2021 has been known only from the localities in the species description: the southern Adriatic, northern Ionian, and northern and western Aegean seas. The additional specimens of this species were collected in central and northern Adriatic Sea. The identification was confirmed by morphological and genetic methods. The morphological and preserved coloration characters were compared with the data from the limited type material and the alternative preserved coloration diagnostic character was suggested. The first data on alive and freshly dead coloration are reported. The phylogenetic analysis was performed on sequenced COI, cytochrome b, and rhodopsin genes. The analyzed molecular markers placed Z. pallaoroi in a distinct clade within ZebrusMillerigobius group. The preference of this species for the very shallow habitat is confirmed and discussed.
\end{abstract}

\section{Keywords}

Adriatic Sea, COI gene, habitat, morphology, new records, Zebrus pallaoroi

\section{Introduction}

The family Gobiidae, with 48 species, represents the species richest family of fishes in the Adriatic Sea (Dulčić and Kovačić 2020; Kovačić et al. 2021). Gobies are also the species' richest family of fishes in the Mediterranean (Kovačić 2020). The known diversity and taxonomy of Mediterranean gobiid species was consolidated in the second half of the $20^{\text {th }}$ century by a series of descriptions and redescriptions of species and genera and by a few review works and books (Kovačić 2020). However, since then a number of new species have been described for the area (Kovačić 2020). Some of these gobies still remain poorly known with only one to a few records in total (Patzner 2021). For those rare, or at least elusive species, every new record provides an increase of the limited knowledge on species geography, ecology, morphology, coloration, etc. The gobiid genus Zebrus de Buen, 1930 has been considered monotypic for nearly half of the century. The subgenus Zebrus de Buen, 1930, containing two species since establishing, was elevated to the rank of the genus by Miller (1966). Gobius thori de Buen, 1928, was synonymized later with Thorogobius ephippiatus (Lowe, 1839) (see Miller 1973). Miller (1977) provided 
the redescriptions of Zebrus as a monotypic genus and of its only species, Zebrus zebrus (Risso, 1827). Recently, Kovačić et al. (2021) described the second species of this genus, Zebrus pallaoroi Kovačić, Šanda et Vukić, 2021 based on the material from the southern Adriatic, northern Ionian, and northern and western Aegean seas, proving morphological and genetic differences between this cryptic species and Z. zebrus. Zebrus pallaoroi, so far known only from the localities mentioned in the original species description, has recently been found on two distant localities in the central and northern Adriatic.

The aim of the presently reported study was to reveal the additional records of recently described Z. pallaoroi, expanding its known range, with notes on its morphology, ecology, and molecular identification.

\section{Materials and methods}

Localities and sampling. The specimens were collected off the city of Split, the central Adriatic Sea, and off Cape Lipica, Oštro, the northern Adriatic Sea (Fig. 1). In order to collect specimens from Split, a $2.5 \%$ quinaldine and seawater solution was used to anesthetize specimens which were subsequently collected by the handnet. Both specimens were found by surveying a shallow and narrow coastal area during low tide in the vicinity of the Institute of Oceanography and Fisheries in Split, Croatia. Cryptic spaces below boulders and pebbles were visually examined in very shallow water. Specimens at Oštro were collected by the application of a rotenone solution in the intertidal bedrock hole. All collected fish specimens were killed by an overdose of quinaldine. The fin clips for DNA analysis were removed and specimens stored in $70 \%$ ethanol solution. The tissue samples for DNA analysis were preserved in $96 \%$ ethanol.

Material. Material collected (standard length + caudal fin length): 1 male, $26.66 \mathrm{~mm}$, caudal fin damaged, PMR VP5043 (Fig. 2A) and 1 female, $21.65+5.56 \mathrm{~mm}$, PMR VP5093, both Cape Lipica, Oštro, the northern Adriatic Sea, Croatia, $45^{\circ} 15^{\prime} 54^{\prime \prime} \mathrm{N}, 14^{\circ} 33^{\prime} 46^{\prime \prime} \mathrm{E}, 28$ July 2021, collected by M. Kovačić; 1 male, $38.47+9.20$ mm, PMR VP5094 (Fig. 2B) and 1 specimen of undetermined sex, $28.01+5.88$, IOR-Zpallaoroi12021, collected on 29 March 2021, both from inside the port of the Institute of Oceanography and Fishery, Split, the Central Adriatic Sea, Croatia, 4330'28'N , 16 ${ }^{\circ} 23^{\prime} 19^{\prime \prime} \mathrm{E}, 26$ April 2021, collected by M. Pavičić and B. Dragičević.

Ecology and geographic distribution. Both individuals collected in Split were found below boulders of approx-

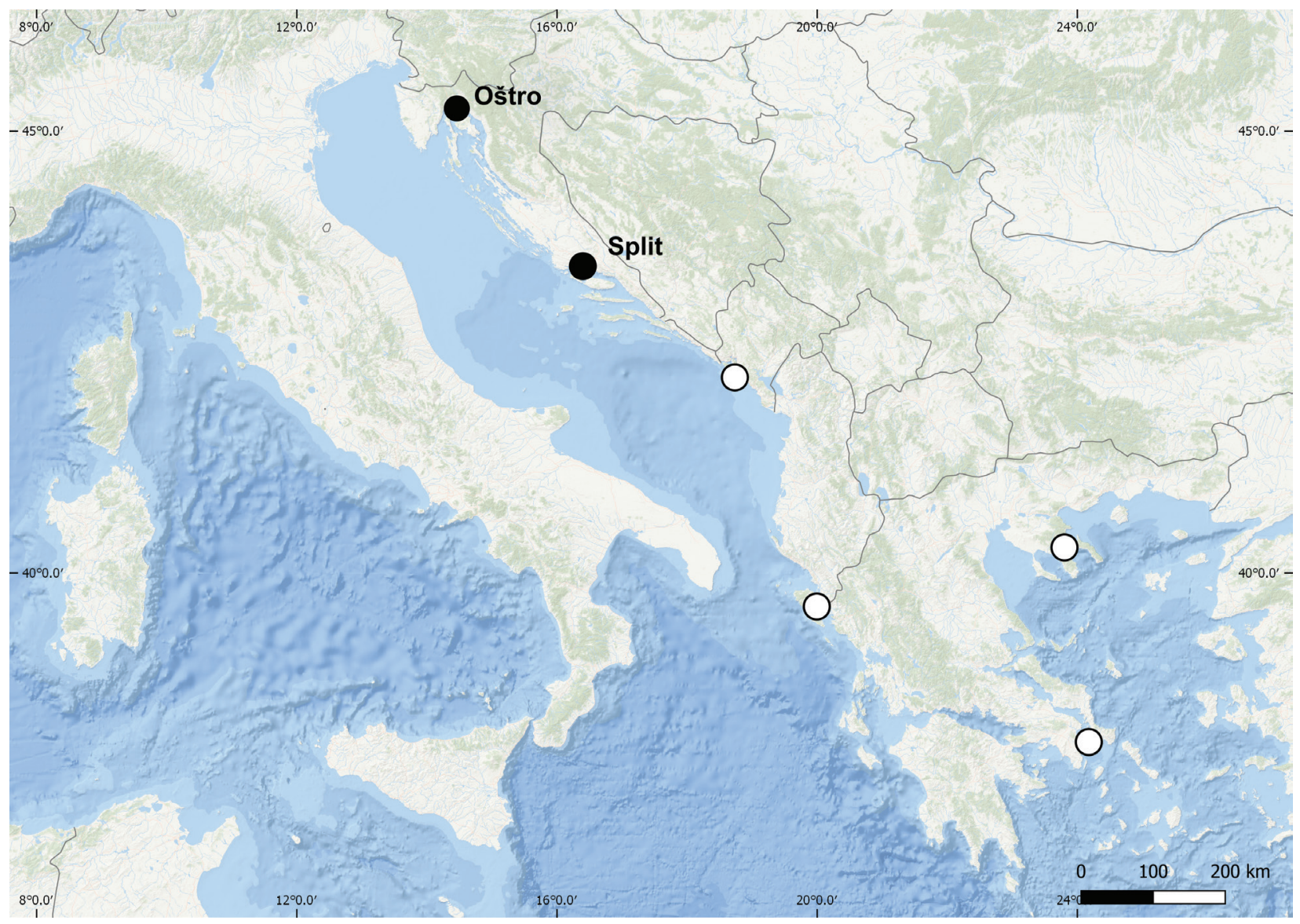

Figure 1. Zebrus pallaoroi present records (•) and the localities from Kovačić et al. (2021) (०). Map source: Esri Ocean Basemap by Esri, Garmin, GEBCO, NOAA NGDC, and other contributors. 


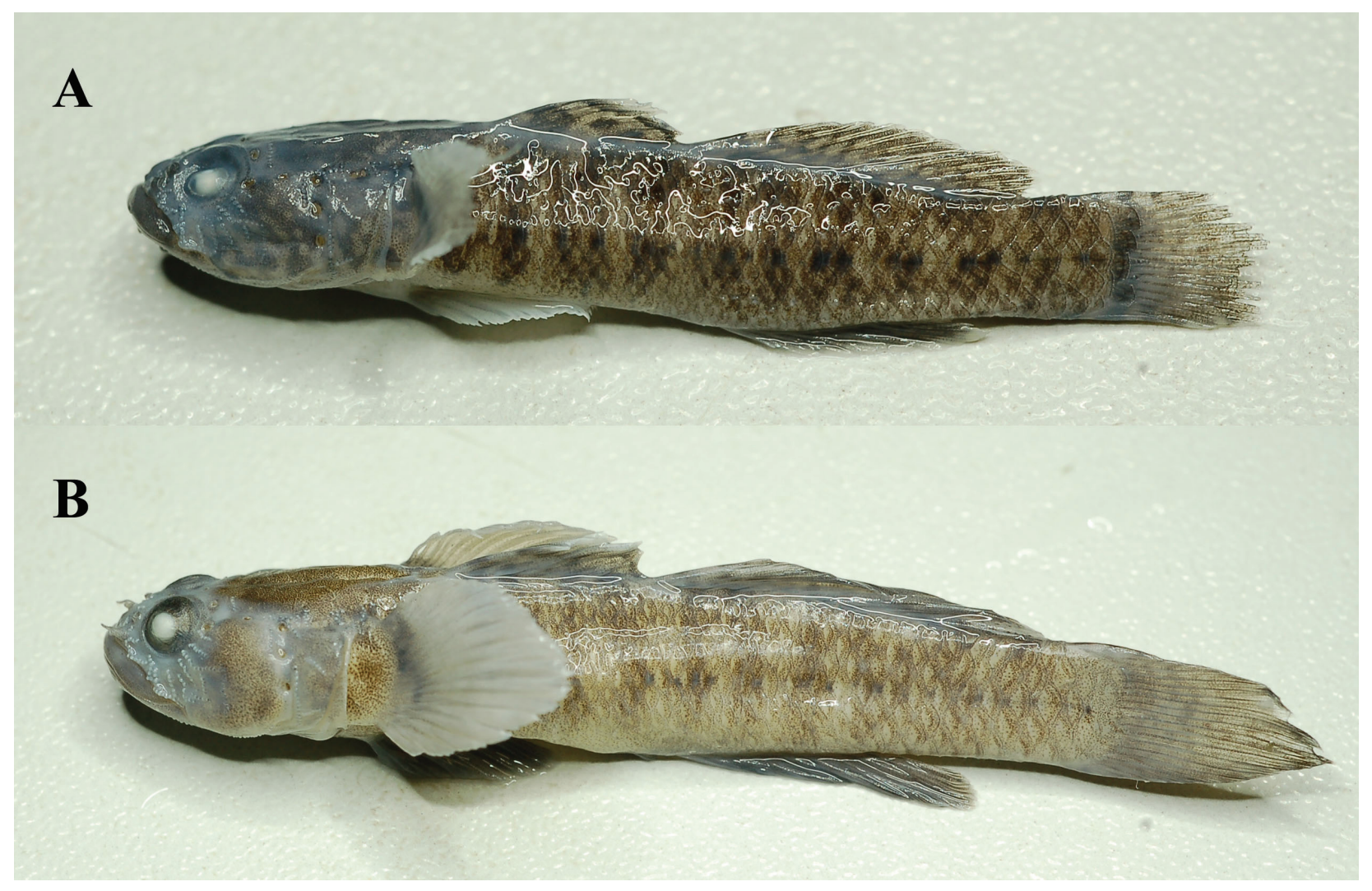

Figure 2. Zebrus pallaoroi: (A) male, $26.66 \mathrm{~mm}$, caudal fin damaged, PMR VP5043, Cape Lipica, Oštro, the northern Adriatic Sea, Croatia; (B) male, $38.47+9.20 \mathrm{~mm}$, PMR VP5094, the port of the Institute of Oceanography and Fishery, Split, the Central Adriatic Sea, Croatia. Photos by M. Kovačić.

imately $20 \mathrm{~cm}$ diameter, which were sparsely overgrown by photophilic algae at a small beach consisting of boulders and cobblestone on top of a layer of medium and coarse gravel, at depths $0.0-0.2 \mathrm{~m}$ at low tide. During the search, several other individuals presumably of the same species have been observed but not collected. The beach was sheltered, situated inside the port (Fig. 3A). There have been no artificial alterations of the beach in terms of beach replenishment at least since the construction of the Institute in 1930. The two individuals from Oštro were found at the rocky cape in the bedrock hole with a shallow surface connection to the sea (Fig. 3B). The bedrock walls of the hole contained crevices and its bottom was covered in boulders. The hole was of about $0.5 \mathrm{~m}$ diameter and of visible depth $0.3 \mathrm{~m}$ to the bottom boulders at low tide, but the real thickness of bottom bolder layers is unknown. After the application of a rotenone solution in the hole, in addition to Z. pallaoroi, Microlipophrys adriaticus (Steindachner et Kolombatović, 1883) and Parablennius sanguinolentus (Pallas, 1814) were also found.

Morphological methods. The morphological data is a combination of characters that positively identify genus Zebrus and species Z. pallaoroi among family Gobiidae in the CLOFNAM area (Kovačić 2020; Kovačić et al. 2021). The terminology and the format style of head canal pores and head rows of sensory papillae followed Sanzo (1911) and Miller (1986). Morphometric and meristic methods fol- lowed methodology in Kovačić et al. (2021). The material was deposited in the Prirodoslovni muzej Rijeka (PMR) and Institute of oceanography and fisheries in Split (IOR).

Genetic methods. Molecular analysis was conducted on specimens PMR VP5043 and PMR VP5093 from northern Adriatic and specimen IOR-Zpallaoroi12021 from Central Adriatic. Total genomic DNA was isolated from fin clips preserved in $96 \%$ ethanol by proteinase $\mathrm{K}$ digestion, followed by a simplified DNA isolation procedure (Laird et al. 1991). After checking DNA quality and quantity by spectrophotometry (IMPLEN N50, Germany), DNA fragments were amplified using HotStarTaq DNA Polymerase kit (Qiagen, Germany) by PCR (Eppendorf Mastercycler Nexus Gx2 thermal cycler) with different primer combinations. A partial fragment of mitochondrial cytochrome $\mathrm{c}$ oxidase subunit I (COI) was amplified with primers FishF1 and FishR1 according to Ward et al. (2005). Primers reported by Kovačić et al. (2021) were used for the amplification of mt cytochrome b (ZzebF1; ZzebR1) and rhodopsin (RHSQF1; RHSQR1). PCR cycling conditions were as follows: an initial denaturing step at $94^{\circ} \mathrm{C}$ for $1 \mathrm{~min} ; 35$ cycles of denaturing at $94^{\circ} \mathrm{C}$ for $15 \mathrm{~s}$, annealing at $50^{\circ} \mathrm{C}$ for $c y t b\left(60^{\circ} \mathrm{C}\right.$ for $\left.r h o\right)$ for $15 \mathrm{~s}$, and extending at $72^{\circ} \mathrm{C}$ for 10 $\mathrm{s}$; and a final extending step of $72^{\circ} \mathrm{C}$ for $10 \mathrm{~min}$.

Product purification and sequencing were performed by Macrogen Inc. (Amsterdam, the Netherlands) on an ABI 3730 automated sequencer. Sequencing was done 


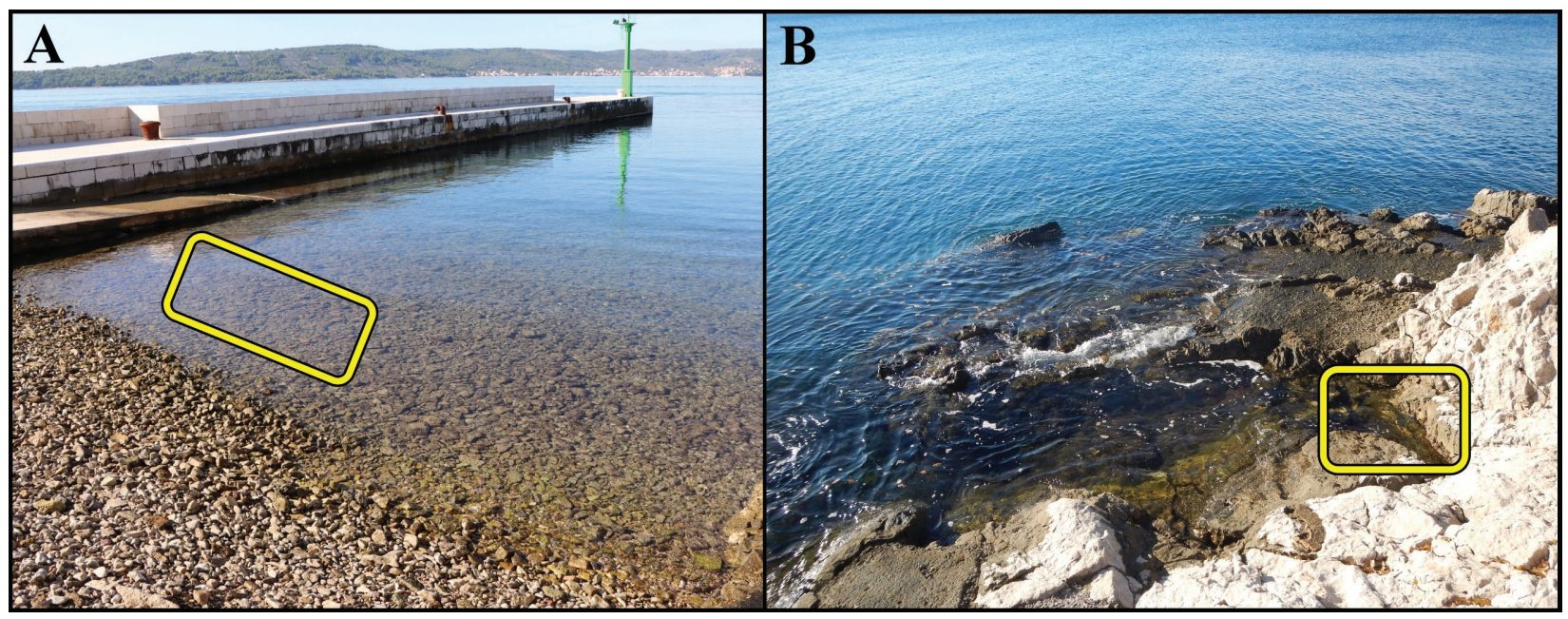

Figure 3. Habitats of collected Zebrus pallaoroi specimens: (A) Split, (B) Oštro. Exact positions where specimens were collected are marked with yellow frame.

from both directions. Chromas Pro 1.5 software (http:// www.technelysium.com.au) was used to evaluate the quality of the chromatogram. BLASTn (NCBI, available online) was used for sequence identification. In addition, sequences of closely related species from GenBank and the Barcode of Life Database (BOLD; www.boldsystems. org) were used for phylogenetic analyses. Sequence alignment was run by the ClustalW tool in MEGA X software (Kumar et al. 2018). The best-fit substitution models in jModelTest (Posada 2008) according to the AIC criterion suggested K2, K2 + I and HKY + G + I for rho, cyt b, and COI, respectively. Therefore, Bayesian phylogenetic analysis was performed using the HKY model in Mr.Bayes 3.2.7a (Ronquist et al. 2012). Two million generations in two independent runs and $25 \%$ of sampled trees were cut as burn-in for the final tree construction. Cheilodipterus quinquelineatus Cuvier, 1828 for COI, Knipowitschia caucasica (Berg, 1916) for cyt b, and Knipowitschia milleri (Ahnelt et Bianco, 1990) for rho were species used as outgroups. The topologies of the trees were visualized in FigTree 1.4.2 (Rambaut and Drummond 2015). The obtained sequences were deposited in GenBank under the accession number (OM893816-OM893824).

\section{Results}

Morphological identification. Morphology was examined on specimens PMR VP5043 and PMR VP5093 from northern Adriatic and specimen PMR VP5094 from central Adriatic. The specimens were identified as Zebrus species by having (1) suborbital papillae of the lateral-line system without longitudinal row $a$; (2) all three head canals present; (3) predorsal area naked; (3) seven transverse suborbital rows; (4) two suborbital transverse rows below row $b$; (5) interorbital papillae absent.

The presently reported material matches $Z$. pallaoro $i$ diagnosis and differs from $Z$. zebrus by all diagnostic morphological characters listed in Kovačić et al. (2021): snout longer than eye, its length 1.1-1.2 of eye diameter (same range as in Kovačić et al. 2021) vs. snout shorter than eye (Miller 1977), its length $0.8-0.9$ of eye diameter in Z. zebrus (see Kovačić et al. 2021); posterior nostril short tube, height 0.9 of anterior nostril height in PMR VP5043 and PMR VP5093, but 0.7 of anterior nostril in PMR VP5094, extending the range 4/5-9/10 for Z. pallaoroi from Kovačić et al. (2021), still different from values for $Z$. zebrus: posterior nostril about $1 / 2$ of anterior nostril (Miller 1977) or 1/4-2/5 of anterior nostril (Kovačić et al. 2021); eyes moderately small, eye diameter is 4.2-4.7 in head length slightly extending the range 4.3-4.7 for Z. pallaoroi from Kovačić et al. (2021), but still different from values for Z. zebrus: $3.4-4.1$ in head length (Miller 1977), 3.1-4.1 in head length (Kovačić et al. 2021) in Z. zebrus; left and right ventrolateral head ridges transversally connected on anterior part by short transversal ridge vs. left and right ventrolateral head ridges disconnected anteriorly by midventral flat area in Z. zebrus (see Kovačić et al. 2021); anterior membrane in midline depth $0.6-0.7$ of spinous ray (about $2 / 3$ in Kovačić et al. 2021) vs. about $1 / 2$ of spinous ray (Miller 1977) and 1/4-1/2 (Kovačić et al. 2021) in Z. zebrus; head canal pores large, pore $\alpha$ diameter 0.5 of the distance between pore $\rho$ and $\rho^{1}$ (about half in Kovačić et al. 2021) vs. head canal pores of moderate size, distance between pore $\rho$ and $\rho^{l}$ about three times or more longer than pore $\alpha$ diameter (Kovačić et al. 2021) in Z. zebrus; suborbital sensory papillae row $5 i$ going downwards to or near the level of row $d$, distance between row $5 i$ and row $d$ much smaller than length of row $5 i$ (absent or much smaller in Kovačić et al. 2021) vs. suborbital sensory papillae row $5 i$ ends downwards distant from row $d$, row $5 i$ length equal or smaller than distance between row $5 i$ and row $d$ in Z. zebrus (see Kovačić et al. 2021).

The diagnostic coloration character of preserved specimens in species description (Kovačić et al. 2021): body with 10 to 11 vertical dark brown bands present along lateral side, first in front of the first dorsal fin, last at end 
of the second dorsal fin, at upper edge about equal or narrower than pale interspaces in between vs. six to nine dark vertical bands at upper edge, broader or equal than pale interspaces in $Z$. zebrus was of variable occurrence in the presently reported material due to blurred lateral coloration pattern on posterior part. However, preserved specimens of Z. pallaoroi on all three morphologically checked preserved specimens had four dark lateral bars about equal or narrower than pale interspaces anteriorly to the second dorsal fin origin vs. three, or just two, dark lateral bars anteriorly to the second dorsal fin origin, broader or equal than pale interspaces, in Z. zebrus.

Coloration of alive under stress and freshly dead specimen. The coloration of the specimen from Split (IOR-Zpallaoroi12021) observed in situ was dark brown, almost blackish, with barely visible vertical bars on the flanks, slightly paler in comparison to the surrounding coloration and conspicuous curved pale band on the head. Very soon after capture, darker coloration subsided and the reticulated brownish and yellowish pattern became visible dorsally appearing as vertical bars laterally; conspicuous pale band visible on the head extended from pectoral fin bases and also partly from the base of the fin rays, over upper portions of operculum and connected at the coronal head section above the eyes.

Genetics. The nucleotide sequences of the $c y t b$ gene and the rho were obtained to ensure species identification. Namely, cyt b (1141 bp) and rho (748 bp) fragments of the study specimens produced significant alignments with sequences of $Z$. pallaoroi from the GenBank with $99 \%$ and 98\% similarity, respectively. Phylogenetic reconstruction inferred by cyt $b$ gene and rho clearly aggregated our specimens with sequences of $Z$. pallaoroi in a separate clade, according to other sequences from the family Gobiidae (Fig. 4). Moreover, phylogenetic reconstruction of the 642 bp long COI fragment revealed a well-supported tree topology in which the studied species Z. pallaoroi from the Adriatic share the same haplotype and form a sister clade with Z. zebrus (Fig. 5). The number of base differences per site between the studied sequences and Z. zebrus was 0.17 , with an overall mean distance of 0.19 between the 46 nucleotide sequences involved.

\section{Discussion}

The morphology of collected individuals matches Kovačić et al. (2021), except for the expanded range of posterior nostril height to 7/10-9/10 of anterior nostril height and eye diameter to $4.2-4.7$ in head length. It could be expected that with the future increased sampling of $Z$. pallaoroi some diagnostic characters could overlap with the range of $Z$. zebrus changing or reducing the species diagnosis. There is always a risk that species descriptions based on a small sample may not encompass the entire variability of species qualitative character states or the entire range of quantitative characters. The majority of the recent Mediterranean Gobiidae species descriptions were not based on large series of specimens, and also many were collected at circalittoral or bathyal depths and were missing alive coloration data (the recent species description reviewed in Kovačić (2020)). However, in order to augment our ichthyological knowledge, and establish conservation needs, waiting sometimes for decades for new species descriptions for large samples, is simply not an acceptable alternative. Didogobius bentuvii Miller, 1966 after more than a half century, is still known only from the holotype, with a number of unknowns for
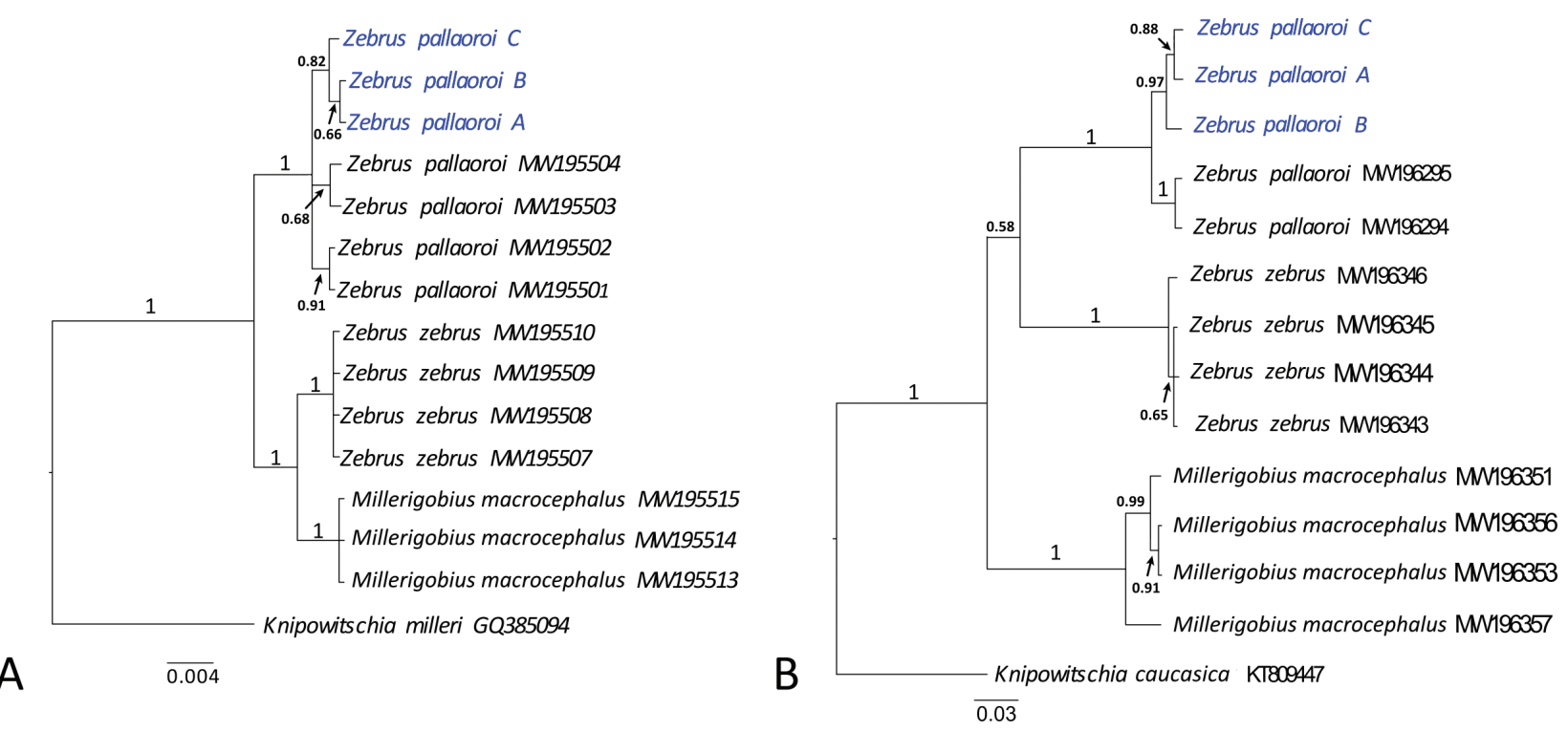

Figure 4. Bayesian phylogenetic tree for the taxa of the gobiid genus Zebrus and Millerigobius, reconstructed from nuclear rhodopsin DNA sequences (A) and mitochondrial cytochrome b (B). Numbers by nodes refer to posterior probabilities. Sequences obtained in this study are labelled with A (IOR-Zpallaoroi12021), B (PMR VP5043), and C (PMR VP5093), while sequences from GenBank are labelled according to accession number. Distance scale provided. 
this species, including the live coloration (Miller 1966). In preserved coloration we suggest replacing the total count of lateral bands as the coloration character for identification of preserved specimens of $Z$. pallaoro $i$ with the anterior count of lateral bands since the coloration pattern can be blurred backwards on lateral side and the bars are not always clearly visible posteriorly: Z. pallaoroi possesses four dark lateral bars about equal or narrower than pale interspaces anteriorly to the second dorsal fin origin vs. three, or just two, dark lateral bars anteriorly to the second dorsal fin origin, broader or equal than pale interspaces in $Z$. zebrus. The first data on the alive and freshly dead coloration of Z. pallaoroi are reported here. However, it should be noted that coloration of stressed individuals in their natural habitat and freshly dead coloration, as well as the coloration of live specimens kept in artificial containers on land, can be altered from the coloration of live, unstressed individuals in their natural habitat. The details of the alive coloration of $Z$. pallaoro $i$ still have to be observed and described (Kovačić et al. 2021).

It is well known that the phylogenetic reconstruction of gobiid genera is complex. In this study, the molecular analysis corroborated the results presented by Kovačić et al. (2021) and successfully confirmed the identification of the specimens as Z. pallaoroi. Namely, all analyzed molecular markers successfully placed $Z$. pallaoroi in a distinct clade within Zebrus-Millerigobius group. The clade of the genus Zebrus is closely related to that of Millerigobius, confirming the interspecific relations observed in the $c y t b$ and rho topologies (Fig. 5). At the time of writing, there was no $C O I$ sequence in public databases that refers to the species $Z$. pallaoroi. Phylogenetic reconstruction of $C O I$ fragments of $Z$. pallaoroi from Adriatic revealed that it forms a sister clade with $Z$. zebrus. Molecular analyses have well-distinguished these two species within the clade. In the future, it would be interesting to analyze the level of genetic differentiation of this species from various geographical areas. Therefore, we encourage additional research effort which could bring to light more records and possibly extend its known distribution further. The present study enabled the first COI sequence deposition of $Z$. pallaoroi in the GenBank.

The findings reported herein extend the known distribution of recently described $Z$. pallaoroi to the central and northern sections of the Adriatic Sea. This extension was the result of an increased research effort driven by the recent recognition of this cryptic species. The two presently reported collection sites were quite sheltered, which was not emphasized in the original description while the then noted preference for the very shallow water is confirmed (Kovačić et al. 2021). In the Adriatic intertidal zone, contrary to oceans and many seas, the small tide and mostly soft sediment or steep bedrock bottoms in the tidal zones rarely shape mediolittoral basins during low tide, so, unlike the coasts with large tides, only a few Adriatic fish species are present in the mediolittoral zone by surviving limited time above the water surface on an exposed rock

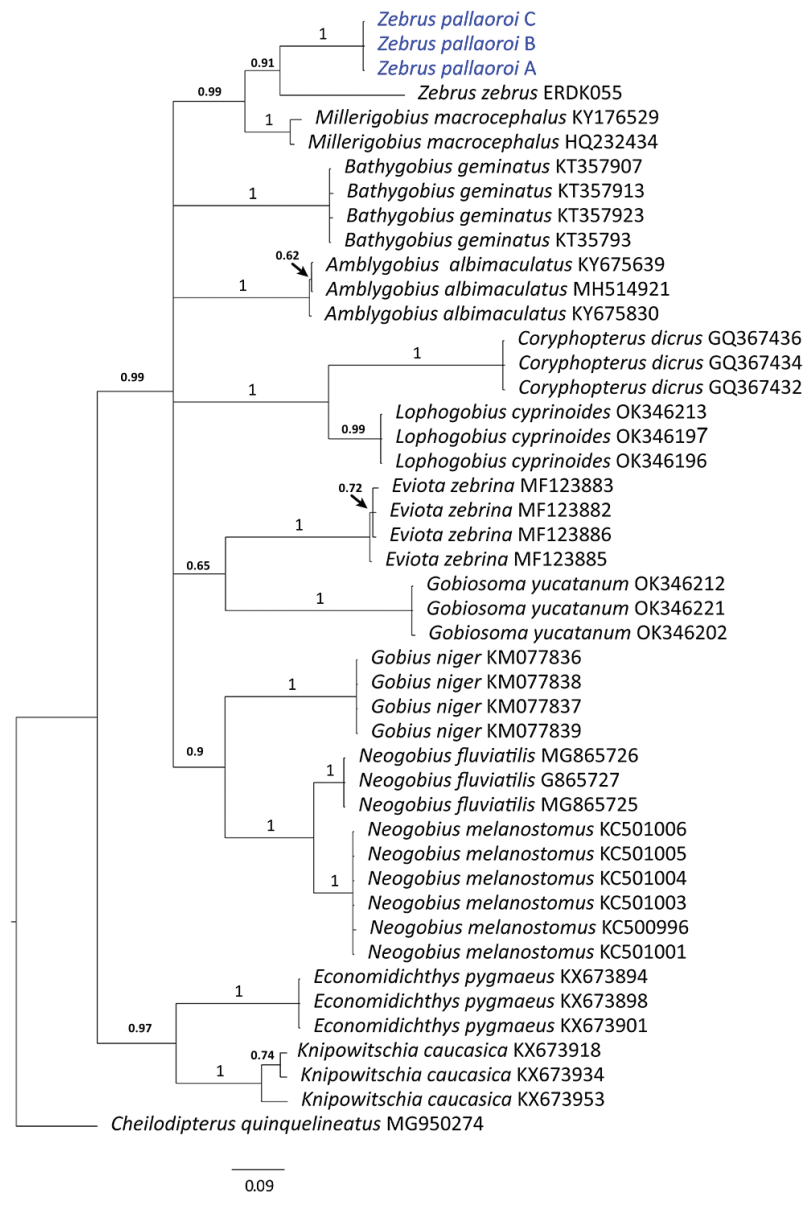

Figure 5. Bayesian phylogenetic tree for the several gobiid genus estimated by partial mitochondrial cytochrome c oxidase subunit I (COI). Sequences obtained in this study are labelled A (IOR-Zpallaoroi12021), B (PMR VP5043), and C (PMR VP5093), while Sequences from Barcode of Life Database (BOLD; www.boldsystems.org) database are labelled according to accession numbers. Numbers by nodes refer to posterior probabilities with distance scale provided.

or under the gravel or boulders. That has been known only for two amphibious blennies on rocks and for Gouania clingfishes living in the intertidal gravel (Wagner et al. 2021). The habitat of Z. pallaoroi collected in Split indicates that $Z$. pallaoroi, with some other fishes, also occurring in shallow infralittoral of 0-1 $\mathrm{m}$ depth inside the boulders or cobbles fields (e.g., Chromogobius quadrivittatus (Steindachner, 1863) and Lepadogaster lepadogaster (Bonnaterre, 1788) (see Patzner 1999, 2021)), could have its upper depth limit expanded to the mediolittoral zone and perhaps could be able to survive diurnal dried periods above water level at low tide. The preference of this species for shallow habitats is also important since those habitats are under heavy anthropogenic impact. Indeed, shallow habitats are under increased threat in Croatia mainly as a consequence of various habitat alterations at the coastline by embankments, beach nourishment, and marine infrastructure construction along the coast in recent decades (Matić-Skoko et al. 2020). About two-thirds 
of the entire Mediterranean coastline is urbanized, and more than half of the Mediterranean coasts are dominated by concrete (Airoldi and Beck 2007); data are not known for the Adriatic but probably are not better. In that sense,

\section{References}

Airoldi L, Beck MW (2007) Loss, status and trends for coastal marine habitats of Europe. Pp. 345-405. In: Gibson RN, Atkinson RJA, Gordon JDM (Eds) Oceanography and Marine Biology: An Annual Review 45. CRC Press, Boca Raton, FL, USA. https://doi.org/10.1201/9781420050943

Dulčić J, Kovačić M (2020) Ihtiofauna Jadranskog mora. Golden marketing - Tehnička knjiga i Institut za oceanografiju i ribarstvo, Zagreb, Split, Croatia, 680 pp.

Kovačić M (2020) Checklist of gobies (Teleostei: Gobiidae) of the Mediterranean Sea and a key for species identification. Zootaxa 4877(1): 75-101. https://doi.org/10.11646/zootaxa.4877.1.3

Kovačić M, Šanda R, Čekovská K, Soukupová T, Vukić J (2021) Zebrus pallaoroi sp. nov.: A new species of goby (Actinopterygii: Gobiidae) from the Mediterranean Sea with a DNA-based phylogenetic analysis of the Gobius-lineage. Contributions to Zoology 90(3): 285-317. https://doi.org/10.1163/18759866-bja10018

Kumar S, Stecher G, Li M, Knyaz C, Tamura K (2018) MEGA X: molecular evolutionary genetics analysis across computing platforms. Molecular Biology and Evolution 35(6): 1547-1549. https://doi. org/10.1093/molbev/msy096

Laird PW, Zijderveld A, Linders K, Rudnicki MA, Jaenisch R, Berns A (1991) Simplified mammalian DNA isolation procedure. Nucleic Acids Research 19(15): 4293. https://doi.org/10.1093/nar/19.15.4293

Matić-Skoko S, Vrdoljak D, Uvanović H, Pavičić M, Tutman P, Bojanić Varezić D (2020) Early evidence of a shift in juvenile fish communities in response to conditions in nursery areas. Scientific Reports 10(1): 21078. https://doi.org/10.1038/s41598-020-78181-w

Miller PJ (1966) A new genus and species of gobiid fish from the eastern Mediterranean. Annals and Magazine of Natural History 13(8): 161-172. https://doi.org/10.1080/00222936508651555

Miller PJ (1973) Gobiidae. Pp. 483-518. In: Hureau J-C, Monod T (Eds) Check-list of the fishes of the north-eastern Atlantic and of the Mediterranean. UNESCO, Paris.

Miller PJ (1977) Gobies from Rhodes and systematic features of Zebrus zebrus (Teleostei: Gobiidae). Zoological Journal of the Linnean knowledge on the distribution of this and other cryptic species with a preference for shallow habitats is essential for the appropriate assessment of species conservation status and successful conservation actions.
Society 60(4): 339-362. https://doi.org/10.1111/j.1096-3642.1977. tb00839.x

Miller PJ (1986) Gobiidae. Pp. 1019-1085. In: Whitehead PJP, Bauchot M-L, Hureau J-C, Nielsen J, Tortonese E (Eds) Fishes of the North-eastern Atlantic and the Mediterranean. Vol. 3. UNESCO, Paris. https://doi.org/10.2307/1444931

Patzner RA (1999) Habitat utilization and depth distribution of small cryptobenthic fishes (Blenniidae, Gobiidae, Trypyterigiidae) in Ibiza (western Mediterranean Sea). Environmental Biology of Fishes 55(3): 207-214. https://doi.org/10.1023/A:1007535808710

Patzner RA (2021) Gobiidae. [Accessed 1 December 2021] http://www. patzner.sbg.ac.at/Gobiidae/GobiidaeSpecies.htm

Posada D (2008) jModelTest: Phylogenetic model averaging. Molecular Biology and Evolution 25(7): 1253-1256. https://doi.org/10.1093/ molbev/msn083

Rambaut A, Drummond A (2015) FigTree, version 1.4.2. [Accessed 1 December 2021] http://tree.bio.ed.ac.uk/software/figtree/

Ronquist F, Teslenko M, Van Der Mark P, Ayres DL, Darling A, Höhna S, Larget B, Liu L, Suchard MA, Huelsenbeck JP (2012) MrBayes 3.2: Efficient Bayesian phylogenetic inference and model choice across a large model space. Systematic Biology 61(3): 539-542. https://doi.org/10.1093/sysbio/sys029

Sanzo L (1911) Distribuzione delle papille cutanee (organi ciatiformi) e suo valore sistematico nei Gobi. Mittheilungen aus der Zoologischen Station zu Neapel 20: 251-328.

Wagner M, Kovačić M, Koblmüller S (2021) Unravelling the taxonomy of an interstitial fish radiation: Three new species of Gouania (Teleostei: Gobiesocidae) from the Mediterranean Sea and redescriptions of G. willdenowi and G. pigra. Journal of Fish Biology 98: 64-88. https://doi.org/10.1111/jfb.14558

Ward RD, Zemlak TS, Innes BH, Last PR, Hebert PDN (2005) DNA barcoding Australia's fish species. Philosophical Transactions of the Royal Society of London. Series B, Biological Sciences 360(1462): 1847-1857. https://doi.org/10.1098/rstb.2005.1716 